\title{
Scratching the surface
}

\author{
Lourdes Torres ${ }^{1}$
}

๑) Springer Nature Limited 2019

This issue contains a range of articles dealing with transnationalism, cultural representations, migration and politics. One commonalty among these heterogeneous essays is a focus on contradictions that are locatable once analysis moves beyond the surface. Assumptions that seemed straightforward become unsettled as authors engage us in a more layered and nuanced analysis.

Jade Power-Sotomayor offers a fascinating exploration of race and culture in Puerto Rico as she deconstructs the racial politics inherent in the creation and maintenance of cultural heroes. She discusses the case of Ramón Rivero, a much-loved blackface performer of the mid-1950s. Rivero was a recognized critic of colonialism and an advocate for workers' rights, yet Power-Sotomayor draws our attention to Rivero's contradictory legacy. Through his performance of "Diplo," Rivero critiqued US imperialism and engaged in philanthropic projects at the same time that he enacted a comedic and dehumanizing representation of blackness. After exploring the reception of Diplo's performances during Rivero's life time, Power-Sotomayor considers the enduring legacy of this figure. She shows how, despite espousing a politics of inclusion and a celebration of Afro-Latinidad, Puerto Rico's continuing acceptance of racist appropriations suggests that the island has never reckoned with its deep-seated racist history and its present-day reality of entrenched antiblackness even within anticolonial discourses.

In the realm of the seemingly progressive transformation of musical traditions, Erin Bauer's essay considers the trajectory of the Tejano Conjunto Festival, an annual multiday event organized by the Guadalupe Cultural Arts Center in San Antonio, Texas, since 1982. She documents how, with evolving technologies of social mass media, this music festival has gone from a local Texas-Mexican regional event to a transnational phenomenon enjoyed by people of diverse nationalities across the country and internationally. As its popularity has grown, the Tejano Conjunto Festival has also incorporated new musical styles and performances very different from its traditional masculine and working-class regional foundations. On many levels this development can be seen as positive, but Bauer also points to what is potentially lost in this evolving

Lourdes Torres

1torres@depaul.edu

1 DePaul University, Chicago, IL, USA 
transformation of conjunto, specifically in terms of the loss of its significance as a site of Texas-Mexican cultural resistance.

The courts are often the last recourse for disenfranchised people seeking justice. In his striking multidisciplinary analysis of juridical doctrine and classic Chicano literary narrative, José A. de la Garza Valenzuela highlights the links between the denial of equitable citizenship rights to queers and to Latino migrants. Through an insightful reading of a 1967 Supreme Court ruling (Boutilier v. Immigration and Naturalization Service) and Arturo Islas's The Rain God, de la Garza Valenzuela asks, "What does it mean to appeal to the very institutions that have procured our exclusion and negation for access to the full rights of citizenship, a demand that has material consequences for same-sex couples and undocumented migrants, while the same strategies of criminalization continue to be deployed against still vulnerable migrant and queer communities made absent through deportation, indefinite detention, and/or murder?" Juxtaposing a reading of legal doctrine and Islas's classic novel, de la Garza Valenzuela demonstrates how immigration policy and the legal system work in tandem to negate the rights of migrants and queers.

Turning to related manners of exclusion, Beth Baker and Alejandra Marchevsky examine the gendered properties of the US deportation system from a rarely studied perspective. While much recent research details the gendered deportation system from the standpoint of the men who are most frequently removed from the US, less attention is focused on the women who are left to fend for themselves, support their families in the US, and quite often send funds to their deported partners. Baker and Marchevsky examine the violence of deportation from the vantage point of the wives and mothers left behind. Victims of policies that result in forced transnationalism, they shoulder the burden of supporting their families without the contributions of men who were usually the ones with the higher-paying positions in construction and other industries. This situation not only impoverishes entire households but also transforms gender dynamics and precipitates the destruction of some families.

In an analysis that focuses our attention on the representation of migrants in recent photojournalism, Kristen Hill Maher and Jesse Elias describe how apparently distinctive representations actually tend to cohere as they variously reflect the intricate workings of neoliberal multiculturalism. With a compelling analysis of a selection of newspaper narratives and accompanying photos, they convincingly argue that although migrants might be variously represented as abject laborers, dangerous criminals, or upand-coming achievers at different stages during their migratory experience, all representations serve to bolster a neoliberal regime that serves US economic needs while it projects a deceptive vision of a benevolent and equitable society. The analysis reminds us of the important place that media holds in supporting the discriminatory status quo, repressive national policies and veiled racist ideologies.

We are also pleased to round out the issue with a timely Reflexiones Pedagógicas essay by Megan Jeanette Myers on using Twitter in a Latinx studies course and a 
moving Vivencias essay by Esteban Loustaunau that documents the powerful storytelling efforts of unaccompanied refugee minors.

Enjoy!

Publisher's Note Springer Nature remains neutral with regard to jurisdictional claims in published maps and institutional affiliations. 